\title{
The Politics of Cape Verdean American IDentitY ${ }^{1}$
}

The Negro immigrant to the United States is faced with grave problems of social adjustment. Not only is he an alien by law and fact, but he suffers a complete change in status by emerging from a group setting where he was the racial majority into one where he becomes part of a racial minority (Reid 1939:35).

Some or even much of what has been designated in the literature as ethnicity might better be considered as varieties of politicized self-identification (Blu 1980:234).

For the Cape Verdean-American, social identity can never be assumed and is never a given. Rather, the issue is continually being reformulated, sometimes at critical personal cost (Halter 1993:173).

\section{INTRODUCTION}

In the United States, the idea of having a "choice" in the construction of identity is made problematic by the social constraints under which racial and ethnic minority groups live. ${ }^{2}$ One such constraint is the system of social classification that has historically polarized U.S. citizens and residents into aggregates of "Black" or "White," and more recently "White" and "non-White," through the hegemonic discourse of racial ascription. This discourse underlies the process of racialization whereby intragroup cultural differences are homogenized under the rubric of race. This phenomenon is most apparent in the contemporary ordering of Blacks, Latinos, Asian Americans and Native Americans into culturally homogenized groups through the U.S. Bureau of the Census. Although the U.S. system of racial classification has become less static over time, the federal government continues to officially classify persons according to race and ethnicity. ${ }^{3}$

GINA E. SANCHEZ is a Ph.D. candidate at the University of Texas at Austin who is currently conducting fieldwork on the negotiation of racial and ethnic identity among Cape Verdeans living in the Roxbury and Dorchester neighborhoods of Boston, Massachusetts.
Michael Omi and Howard Winant (1986:75) have defined racialization as a process whereby "previously racially undefined groups" are situated within a prevailing racial order. Nowhere is the practice of racialization more apparent than in the experience of persons immigrating to the United States. Immigrants of African descent, in particular, are directly confronted with this system of racial classification; they are often assigned a racialized status as "Black" or "African American," on the basis of visible and/or suspected African ancestry, without regard to their particular cultural and political histories. In response, these so-called "Black immigrants" and their descendants may negotiate their identity within certain parameters of choice: they may resist racial ascription by asserting a "national" or "ethnic" identity (e.g., "Haitian"); they may adhere to a bi-national identity (e.g., "Jamerican"); or they may align themselves locally with the African American community and globally with the international African Diaspora by identifying as "Black" (see, Bryce-Laporte 1972; Butcher 1994; Foner 1987; Reid 1939; Waters 1994; Woldemikael 1989a, 1989b).

Cape Verdean Americans, as persons of African and Portuguese descent, represent one such group who have faced this dilemma of racial classification in the United States. The Cape Verde Islands are a ten-island nation located approximately 283 to $\mathbf{4 4 8}$ miles off the coast of Senegal, West Africa (Lobban 1995:4). ${ }^{4}$ Cape Verdeans began immigrating to the United States during the late eighteenth century. Like other immigrants, Cape Verdeans and their descendants have had to constantly negotiate their cultural, political and national identities in light of new social forces impacting their lives in the United States. One aspect of this negotiation entails the reconciliation of a Cape Verdean cultural identity with a socially-ascribed, racialized minority status as "Black."

Halter has described this process as the "juxtapos[ition] of one's adaptation to new cultural norms within the suffocating strictures of racial categorization in American society" (1993:174). Many Cape Verdean Americans have resisted the "Catch-22" of identifying as either "White" or "Black" by asserting 
a national and cultural "Cape Verdean" identity, while others have assumed a politicized identity as "African American" or "Black." Still others have chosen to identify as "Portuguese" (also understood as "White") in their attempt to escape the stigmatization attached to "blackness" or to African ancestry.

The following essay explores the impact of self-identification and outside ascription on Cape Verdean American identity formation, which can be interpreted as Diasporic and transnational in nature. Specifically, I am interested in the ways in which Cape Verdean Americans, especially those of second and third generation, construct themselves as members of both the Cape Verdean and African American communities of the United States. This construction of what I and others have called "Cape Verdeanness" is manifested in a range of experiences and practices that embody the historical memory, politics and everyday, lived experiences of this racial/ethnic group.

I evoke the concept of the African Diaspora as a tool through which to examine the politics of racialethnic self-identification with respect to Cape Verdean Americans. Some of the more fruitful results of engaging in such a project would be to answer the following questions: Can Cape Verdean Americans who strongly acknowledge their African ancestry, or who have lived a "Black" experience in the United States be considered part of the African Diaspora in the Americas? Why do some Cape Verdean Americans identify more with the African American community than with any other? What are the consequences of self-identifying as "Black" in the United States? Answers to these questions go far in determining the politics of Cape Verdean American identity as a multiple construction of race and ethnicity. Moreover, they highlight the ethnic diversity that exists within the African American community, as composed of native and foreign-born Black people.

I have problematized my position as author by examining a racial/ethnic group to which I belong. As a "native" anthropologist, "forced to confront the politics and ethics of [my] representations" (AbuLughod 1986:142), I acknowledge that to consider Cape Verdean Americans as members of the African Diaspora is a political exercise, indicative of those who, like myself, have lived a "Black" experience in the United States.

\section{HISTORICAL ROOTS AND ROUTES}

The Republic of Cape Verde, composed of ten islands and five islets, was uninhabited upon "discovery" in
1460, although Arabs and Africans may have established residency on the islands prior to the mid-fifteenth century. ${ }^{6}$ Developed into a major stopping point in the triangular slave trade, Cape Verde became a colony of Portugal from the late 15th century until 1975. Like other Iberian colonies, Cape Verde witnessed an era of African enslavement (1460-1878), the subsequent proliferation of a racially and culturally mixed population, an extended period of colonial neglect, and finally the struggle for independence.

During the early sixteenth century, Cape Verde served as a colonial experiment for the plantation-based economy that the Portuguese would replicate in Brazil and in other colonies. With the advent of cotton and sugar cultivation on the islands of Santiago and Fogo in particular, the Portuguese soon after enslaved Wolofs, Fulas, Mandinkas, and Beafadas primarily (Lobban 1995:69; Meintel 1984:23), with additional indentured laborers coming from west-central Europe, Asia and Brazil (Pap 1981:113). After 1600, most of the enslaved brought from mainland Africa to Cape Verde continued onto Brazil and the Caribbean after being "acclimatized" or baptized into the Christian faith and taught the respective colonial language. Such slaves were also exported to Colombia, Mexico, the Canary Islands, and Seville (Davidson 1989:26).

Along with the Portuguese and the Africans, Cape Verde's settler population was also composed of Castillian and Genoese explorers who were later joined by French and English traders, occasional pirates, and political exiles or degredados who were banished to the islands as a form of imprisonment. Meintel's (1984) anthropological study of race and culture in Cape Verde reveals that as a result of extensive miscegenation facilitated by exile and slavery, a tripartite classification of people - into categories of Branco (White), Mestiço (Mulatto), or Preto (Black) ${ }^{7}$ - was promoted by the late sixteenth century, with each sector distinguished on the basis of phenotype and by degrees of assimilation to a "national," Portuguese culture (see also, Lobban 1995:54). In addition, both prior to and after abolition, the division of people of African descent into "free" and "not free" gave way to the emergence of skin color gradations as a primary means of categorization. The census of 1856, for example, cites the use of 17 such labels (Davidson 1989:11). The Mulatto sector of the population constituted the majority; this is still the case, as they account for approximately $73 \%$ of the archipelago's population. 
During the early seventeenth century, Santiago declined in importance as a trading center, succumbing to high slave prices and competition brought about by the Guinean Coast slave trade. This, in turn, led to the decrease in slave importation to this island (Meintel 1984:84). Moreover, slavery proved to be less lucrative in Cape Verde than in its colonial counterpart, Brazil, given the arid climate and exhausted soil after years of exploitation. For these reasons, the Portuguese abandoned the system of plantation slavery officially as of 1869 , although the internal slave trade persisted illegally until 1878 .

After losing its commercial importance as a supplier of cotton, maize and coffee, Cape Verde continued to function as a "repair shop" for slavers and whalers through the nineteenth century (Meintel 1984:18). Once free, the ex-slaves upward mobility into the landlord class in Cape Verde was contingent upon locale and historical patterns. As in Brazil, free Mulattos filled those interstitial positions that were previously unavailable to slaves and undesirable to the Portuguese. Yet, abolition did not fundamentally alter the economic and political condition of the former slave. Even today, the society of Cape Verde still exhibits the social and economic patterns typical of its antebellum era, evident in the persistence of sharecropping and absentee landlordism, for example.

Cape Verde remained a colony of Portugal until July 5, 1975, when it became independent after more than twenty years of political and armed struggle, led by Pan-Africanist Amilcar Cabral and the PAIGC (African Party for the Independence of Guinea and Cape Verde). Unlike other wars fought for African liberation, the struggle for Cape Verdean independence was waged militarily in West Africa, with the islands serving primarily as ideological support. The Cape Verdean independence movement was also financed by the islanders as well as from expatriates and American-born Cape Verdeans living in the United States. Initially after gaining independence, Cape Verde and Guinea-Bissau were united as two nations governed by one political party until the early 1980 s, when Cape Verde officially sought recognition as an independent republic (Cubie 1994). Cape Verde has since distanced itself politically from mainland Africa, with its promotion of a democratically-elected government and the adoption of a new flag as of 1992, whose red, white and blue colors have replaced the red, yellow and green widely associated with Africa. Today, Cape Verde houses a population of approximately 380,000 people.
The racial composition of Cape Verde as a result of its colonial experience differs from island to island. Brava, for example, attracted more White settlers from the Azores and Madeira and relied less upon slave labor. Fogo and Santiago, on the other hand, contain populations reflecting an historically strong African presence, as is also the case in Maio, whose population established early links to Africa through the slave trade, commerce, and migration (Meintel 1984:26).

Along with phenotype, Cape Verdeans also rely on social and economic attributes such as ancestry, wealth and community status to determine one's position within the social hierarchy. Branco, for example, was used to describe persons who were not only of "apparent European origin" but also "in positions of power" (Lobban 1995:54). Moreover, according to Richard Lobban (1995:57), "higher levels of wealth, power, educational status, and class position... lighten[ed] a person's 'racial' classification, while poverty, uncouth behavior, and illiteracy "darkened it." This ideology of social class difference created inter-island conflict by promoting the idea that a certain island, skin color and/or phenotype was superior to another (Halter 1993:144). Yet, color and class status correlated in Cape Verde, as is still evident in the disproportionate amount of darker-skinned persons living in poverty and unable to emigrate to the United States (Rogers 1980:198). Cultural distinctions among Sotavento and Barlavento islanders are also apparent in clothing, language, and food preparation, as was the case during the nineteenth century. ${ }^{8}$ In general, these sociocultural dynamics of island identity remained with Cape Verdean migrants as they entered into the racially stratified society of the United States.

\section{IMMIGRATION}

Cape Verdeans migrated from the islands as early as the eighteenth century as a means of escaping the persistence of famine, volcanic eruption (the archipelago's origins) and drought, the latter of which is ongoing. ${ }^{y}$ Cape Verdeans are often referred to as one of the few groups of African descent to have migrated voluntarily to the United States. Yet, the ecological hardships endured by Cape Verdeans have led one scholar (Barrows 1990) to argue that Cape Verdean migration was initiated more out of necessity (see also, Halter 1993:24).

The pattern of Cape Verdean migration from the islands has been described as circular, permanent and contractual (i.e., labor migration) in nature (Lobban 
1995:58). According to Joe D'Alessandro (1983:73), Cape Verdean immigration to the United States can be divided into three waves: $1850-1899 ; 1900-1924$; and post-1957. A recent estimate of actual arrivals is offered by Halter (1993:45), whose analysis of passenger lists (from ship manifests) and official records shows that between 1820 and 1976, approximately 35,000-45,000 Cape Verdeans immigrated to the United States. Halter adds that an annual average of 913.6 persons have entered between 1975-1980 (1993:46). These more recent migration flows which occurred at the outset of independence constitute a fourth wave that continues to this day.

The first wave of Cape Verdeans who immigrated to the New England area did so as crewmembers of "Yankee" whaling ships. ${ }^{10}$ From the mid-eighteenth century onward, the whaling industry in the United States was centered on the islands of Martha's Vineyard and Nantucket, as well as in New Bedford, Massachusetts. Because their whaling expeditions took them into the Atlantic Ocean, New England whalers usually anchored off the coast of the Atlantic islands of the Azores and the Cape Verde Islands (i.e., off the coast of Brava), to refurbish their supplies. Once there, these whalers also began recruiting seafarers and fishermen from Cape Verde (primarily from Brava), the Azores, and Madeira as cheap laborers (Wolforth 1978:9). Don Brown notes:

It was the custom in this period to stop at the Azores and Cape Verde Islands, both Portuguese holdings, to get the fresh provisions so necessary in preventing scurvy. At the same time, ship captains replenished their crews, replacing deserters and those who had succumbed to the rigors of crossing the Atlantic with the islanders, who were excellent seamen (1987:27).

By the turn of the twentieth century, improvements in sailing techniques led to increased trade between the East Coast and these Atlantic Islands, thus facilitating Cape Verdean settlement in New Bedford and Boston, Massachusetts, as well as in Providence, Rhode Island (Goncalves 1983:113).

Although the whaling industry went into decline as of the late nineteenth century (due to the discovery of petroleum in Pennsylvania which replaced whale oil as domestic fuel), Cape Verdeans sustained the industry well into the twentieth century (Pap 1981:133). During the 1920s, Cape Verdeans bought and converted most of the whaling vessels into "packets," or cargo and passenger ships, which further assisted Cape Verdean entry into the country (Pap 1981:83). This so-called "packet trade" between Cape Verde and New England continued into the early 1930s and officially ended with the last voyage of the schooner Ernestina in 1965 (Lobban, Coli, and Tidwell 1985:33). ${ }^{11}$ Cape Verdeans continued to immigrate to the U.S. via airline travel that had improved during the 1940s and 1950s.

In addition to whaling, many Cape Verdean immigrants were contracted to engage in seasonal work as pickers on the cranberry bogs of Harwich and the Falmouth-Mashpee areas of Cape Cod, Massachusetts (Wolforth 1978:43; see also, Almeida 1978:54; Halter 1993). ${ }^{12}$ Cranberry harvesting in the United States began in the $1850 \mathrm{~s}$, with a labor force comprised of Finns, Poles, and Italians (Nunes 1982:10; Halter 1993:99). By 1910, Cape Verdean migrants dominated this industry, particularly those from Fogo, since these islanders had the most experience in an agrarian-based economy. Women and children played a prominent role in the sustainment of the cranberry industry. Because their hands were considerably smaller than those of men, they were able to pick the cranberries at a faster and more efficient rate. The experience of my grandmother, mother and aunt attests to this phenomenon of women ascending the back of pick-up trucks with their children to engage in the back-breaking work on the bogs from the 1920s through the 1950s. The cranberry and whaling industries, in addition to fishing and textile industries, stimulated a steady flow of migration between the islands and southeastern New England. Immigration to the United States as an option for Cape Verdeans became restricted in 1917 through the enactment of a quota law which restricted European and Mexican immigration specifically (Sánchez 1993:55). Cape Verdeans were affected by this quota law given their status as Portuguese colonials. Immigration for all foreign nationals was later curtailed entirely with the Immigration Acts of 1921 and 1924. ${ }^{13}$ These acts significantly decreased Portugal's annual quota, from 2,520 persons in 1921 to 2,465 in 1922, 503 in 1924, and 440 in 1929 (Pap 1981:80). Despite the immigration reforms initiated in 1952 (ending the racial quota system) and in 1965 (easing entrance restrictions for "Third World" countries), Cape Verdean migration still proved to be a difficult task. ${ }^{14}$ Since Cape Verde was a colony of Portugal, their entry quota amounted to 200 visas per year or, one percent of Portugal's visa quota. Cape Verdean migration was negatively affected by this entry quota system from 1965 to 1975 , 
the year when Cape Verde achieved independence and its annual quota was raised to 20,000 (Rogers 1980:198).

Although Cape Verdeans did not intend on permanent settlement in the United States, conditions in the United States - despite working for lower-thanminimum wages and living in impoverished neighborhoods - appeared more economically attractive and ecologically stable. Today, the Cape Verdean Diaspora community spans the globe, yet is still heavily concentrated in Massachusetts, Rhode Island, and California. In 1990, the Cape Verdean population living in the United States was estimated at 400,000 , nearly the same amount of persons still living in the islands.

\section{CAPE VERDEAN IDENTITY (-IES)}

An examination into the ways in which Cape Verdeans have self-identified over time provides insight into the complexity of the Cape Verdean experience as lived in the United States. During the nineteenth century, Cape Verdean migrants tended to identify themselves on the basis of island (e.g., Brava), country (Cape Verde), or nationality (Portuguese). With respect to island of origin, Halter (1993:43) contends that upon arrival into the United States, Cape Verdean immigrants identified themselves as "Bravas" or "Fogos," for example. ${ }^{15}$ Meintel Machado offers a similar argument, stating that "most Cape Verdeans came from rural areas of small islands and defined themselves as being from a certain village, or in other contexts, from a certain island" (1981:254). This practice of self-identifying with an "imagined" (Anderson 1991[1983]) island homeland is still evident and observable in contemporary patterns of communication among Cape Verdean Americans. ${ }^{16}$ Upon meeting a fellow Cape Verdean for the first time, one of the first questions often asked of me is, "What island is your family from?" Likewise, according to Nunes (1982:5), intragroup acceptance is often based on island of origin, as well as class and phenotype.

By contrast, Jose da Silva Goncalves argues that since the Cape Verdean whalers of the early nineteenth century did not settle in the United States right away, these migrant seafarers maintained a "Cape Verde Islander" identity (1983:113). This identity was promoted primarily through continuous maritime voyages initiated in New England that called for their travel between the Azores and the islands for months at a time. This identity construction also suggests a lack of emphasis on identifying by race given their previous status as the majority in the islands.
At the turn of the twentieth century, however, Cape Verdeans increasingly referred to themselves as "Portuguese." This self-designation illustrates the phenomenon of Cape Verdeans gaining entry into the United States as Portuguese nationals, possessing Portuguese passports that listed the skin color and not the race of the passport holder (Cubie 1994:6). In other words, Cape Verdean migrants were described on their passports as Moreno, Mulato, Blanco, Negro, etc., instead of "Black" or "White" or even "Portuguese." The early twentieth century marked a "golden age of racism" in the United States; Cape Verdean migrants utilized the label of Portuguese not only to indicate "nationality" but to distance themselves socially and culturally from the larger African American community. This historical pattern of distancing is explained in detail below.

The practice of Cape Verdeans calling themselves "Portuguese" has persisted and can be witnessed within contemporary Cape Verdean American society. This is particularly true of first and second generation descendants who continue to refer to themselves and to other Cape Verdeans as "Portuguese." My grandmother's love of Cape Verdean music is one example of this; to her, it is "Porchugee [Portuguese] music." However, the employment of "Portuguese" instead of "Cape Verdean" also points to the possibility of the former existing as a euphemism for the latter. Whenever I obnoxiously ask my grandmother "What's Portuguese music?" she is always quick to say, "You know, ... Cape Verdean music." Each of these early self-representations would be challenged when confronted by the system of racial dichotomy that was in place in the United States.

\section{OFFICIAL ASCRIPTION: THE CENSUS}

Cape Verdean American efforts at self-identification have been mediated by the official classification of the U.S. Census which, over the years, has counted persons of Cape Verdean ancestry as White, Portuguese, Black/African Portuguese, "Bravas" (Halter 1993:7), Colored, or "(Other) Atlantic Islanders" (Pap 1981:54). Self-categorization was not an option until 1970; prior to this time, as Jack Campisi points out, "race was determined by the census taker from a limited list of choices. The same held true for marriage, birth, and death notices, which relied on the eye and attitude of the official" (1991:28). In addition, the Immigration and Naturalization Service (INS) has traditionally classified Cape Verdean immigrants on the 
basis of physical approximation to "White" or "Black;" if considered White, they were labeled Portuguese, and if Black, they were labeled "Black Portuguese" or "African Portuguese" (Halter 1993:35). Since they ranged in skin tone and phenotype, Cape Verdean families, according to these official documents, contained "Black" and "White" members as a result of racial classification based on physical appearance.

Through these practices, the Portuguese have historically been considered a White "race or people" as distinct from Cape Verdeans and other Atlantic Islanders who were considered "African (Black)" or of the "colored race" (See, Pap 1981:44; Wolforth 1978:22). Prior to 1920, for example, the Census recorded Azorean, Madeiran, and Cape Verdean immigrants as "all others," distinguishable from Portuguese immigrants (D'Eca 1980 [1939]:367). As of 1920, however, the Census included the category "(Other) Atlantic Islands" to distinguish Cape Verdeans from Azoreans (Pap 1981:54). Each of these Census classifications indicate the way in which the African ancestry of Cape Verdeans was utilized as a marker of difference.

The contemporary construction of "official" identity, as initiated by the Census, allows Cape Verdean Americans to classify themselves racially and ethnically. However, it was only in the 1980 Census that "Cape Verdean" was included as an option for ethnic ancestry on the long form. ${ }^{17}$ Prior to this time, those Cape Verdeans who rejected such labels as "Black Portuguese," for example, often checked off "Other" and wrote in the necessary descriptive information. An interesting observation to be made from this census data is not only how the government "otherized" Cape Verdeans through the Census, but also how Cape Verdeans themselves appropriated this label as a means of empowering themselves as Other. There are many Cape Verdean Americans, living within and outside of the New England area, who still choose to write in "Cape Verdean" on the Census and similar documents as a means of asserting their unique Cape Verdean ethnic experience.

Yet, even in 1980, some Cape Verdean-Americans still self-identified as Portuguese (Halter 1993:35). The Census for 1980, for example, recorded that 616,322 people self-identified as "being of Portuguese ancestry" while another 407,989 identified themselves as "having multiple ethnic ancestry with Portuguese being part of their ancestry" (Williams 1983:27). Cape Verdean Americans may have been included in both of those figures, since there are many who still call themselves "Portuguese." This is particularly true of first and second generation Cape Verdean Americans most of whom are now in their 50s and over.

\section{THEORIZING THE AFRICAN DIASPORA}

The dialectical relationship between self-identification and official ascription has rendered Cape Verdean identity formation a process of ongoing negotiation. Contemporary constructions of Cape Verdean American identity indicate a promotion of a dual sense of peoplehood, as Cape Verdean and as Black. This Cape Verdean "double consciousness" is manifested primarily in cultural practices and everyday lived experiences. Yet, Cape Verdean American identity also contains elements of transnationalism. Before analyzing the Cape Verdean American experience as an African Diasporic one, it is necessary to delineate what exactly is meant by the term "African Diaspora." This is by no means an easy task. The term is often evoked to describe a wide variety of historical experiences, peoples, places, memories and imaginations.

Pan-Africanist scholars (e.g., Padmore 1956) were the first to conceptualize the African Diaspora as a cultural aggregate of individuals of African descent. Of Greek origin, diaspora "originally referred to the first Babylonian exile of the Jewish people and was later applied to their subsequent tragic dispersions" (Drake 1982:342). Pan-Africanists employed this term to describe persons who are of African descent living outside of the continent of Africa whose dispersal - as a consequence of the "economics of slavery" and its aftermath - facilitated a shared experience of international oppression and racial terror. St. Clair Drake (1982:343), in defining a frame of reference of Diaspora studies, conceptualizes traditional Pan-Africanist activities as "a conscious and deliberate movement... [developed] within various parts of the Black world to increase cultural contacts between its diverse segments and to unite them in the pursuit of common interests." For Drake, African Diaspora studies carried out under the auspices of Pan-Africanism "must contribute toward maintaining and reinforcing Black consciousness and must be oriented toward the goal of fostering understanding, solidarity, and cooperation throughout the Black world" (Drake 1982:343).

Studies of the African Diaspora have also been linked to those of the Jewish Diaspora. Contemporary research on the Jewish Diaspora, conducted by Daniel Boyarin and Jonathan Boyarin, 
offers an alternative conceptualization of Diaspora, one not predicated on a "myth of autochthony" but one that considers "subject-position [as] founded on generational connection and its attendant anamnestic responsibilities and pleasures" (1993:701). This conceptualization takes into consideration the genealogical moment of "family, history, memory and practice" as it problematizes essentialistic notions of the bases of identity such as "claims to autochthony and indigenousness" (Boyarin and Boyarin 1993:714). In defining Jewishness as a Diasporic, "disaggregated" identity, the Boyarins (1993:721) explain how it is "not national, not genealogical, not religious, but all of these in dialectical tension with one another." Theirs is also a conceptualization of Diaspora that privileges the loyalty of "memory of place" over "place" itself (Boyarin and Boyarin 1993:719). This contextualizes Diaspora identity in more fluid terms, as dynamic and unbound to a specific territory.

During the last two decades, a number of theorists (Clifford 1994, Gilroy 1987, Gilroy 1993, Mercer 1994, Walters 1993), including the Boyarins (1993), have problematized African Diaspora studies; all attempt to theorize the Diaspora in more complex terms. Others (Appiah 1992, Gilroy 1987, Helmreich 1992) have critiqued the discourse of Diaspora that centers around essentialism. One of the main criticisms of the Pan-Africanist paradigm of Diaspora has been its apparently essentialist view of race and its role in defining Diaspora identity. Kwame Appiah (1992) criticizes Pan-Africanist scholars for employing race as a means of biologically rooting the African Diaspora. Similarly, Paul Gilroy (1993) faults Pan-Africanist views of the African Diaspora as essentialistic in their portrayal of Diaspora identity as naturally linked to a common (African) heritage and homeland. Gilroy (1987) is also critical of those Pan-African theories that espouse ethnic absolutism, that is, the idea of race as static and immutable.

Gilroy (1993) has made an invaluable contribution to the study of the African Diaspora, reconceptualizing the African Diaspora in more fluid terms than his Pan-Africanists predecessors through a critique of essentialized discourses. Employing historical, musical and literary genres, Gilroy's ambitious work offers an alternative term "Black Atlantic" as a means of explaining theways in which Black Diasporic culture transcends national boundaries. He uses the metaphor of travel as manifested in ships and trains to illustrate the interconnectedness of Diasporic cultural formation, as occurring on both sides of and between the Atlantic. This travel metaphor is also embedded in the idea of the Middle Passage as a point of conjuncture linking people to a common experience of slavery and racial terror across space and through time.

Through this conceptualization, Gilroy emphasizes the global movement (or "routes" traveled) of people, the sociocultural changes involved in such movement, and the transnational ties (or "roots") rendered by this experience. Moreover, Gilroy's Black Atlantic attempts to situate people of African descent beyond the confines of "race," culture or color, into a space where international movement and countercultural survival strategies in response to modernity are considered as well.

James Clifford (1994), similar to Gilroy, theorizes Diaspora identity as characterized by hybridity and cosmopolitanism. This perspective, which envisions the Diaspora experience as an entangled occupation of the "space between pre- and postmodernism," is supported by Clifford's emphasis on the here/there, loss/hope aspects of the discourse surrounding Diaspora consciousness (Clifford 1994:304). Tentatively defining Diaspora as "an adaptive constellation of responses to dwelling-in-displacement," he contextualizes Diaspora identity as formed against the nation-state and as manifested in countercultural activities of resistance and accommodation. In this sense, Clifford theorizes the Diaspora and Diaspora identity within the dynamics of historical movement, social memory and strategic survival.

Clifford also distinguishes Diaspora identity from other forms of transnational identity. In differentiating between theories of "borderlands" and Diaspora, Clifford states that:

Borderlands are distinct in that they presuppose a territory defined by a geopolitical line: two sides arbitrarily separated and policed, but also joined by legal and illegal practices of crossing and communication. Diasporas usually presuppose longer distances and a separation more like exile: a constitutive taboo on return, or its postponement to a remote future (1994:304).

Clifford does admit, however, that the theoretical distinction between Diasporic and other transnational identities cannot be drawn hard and fast. That is, there exists overlapping conceptualizations of transnational identity; for example, how borderlands have "Diasporic dimensions" and visa versa. (Clifford 
1994:303).

Diasporic identity formation has often been linked to questions of space, place, and community formation. Lavie and Swedenburg (1996:14) define Diaspora as "the doubled relationship or dual loyalty that migrants, exiles, and refugees have to places - their connections to the space they currently occupy and their continuing involvement with "back home." This conceptualization suggests an event of physical displacement of a group of people who are thereafter connected by that experience. Anderson's (1991[1983]) concept of "imagined community," in particular, is useful in understanding they dynamics of a group of people enjoined by a shared sense of connectedness and belonging. The Boyarins' description of an imagined community in the Jewish example is equally illustrative of the Cape Verdean experience: "Contact with other people who share the name of a given identity and seem to feel organically connected to a community can produce a sense of nostalgia even in one who has never been near the things that the community does" (1993:704). This is certainly the case for third and fourth generation Cape Verdean Americans who feel as connected to Cape Verde and Cape Verdean cultural identity as the newly arrived migrant.

At this point, African Diaspora identity can be conceptualized as one that enjoins a group of people by their collective social memory of common historical experiences (e.g., slavery; racial terror; migration) as well as by a common African ancestry, "imagined" or otherwise. From the above discussion of early and contemporary theorizations of the African Diaspora, one can delineate a number of axes upon which a definition of Diaspora is based. Since the concept of Diaspora contains racial, cultural and experiential components, it has been used to describe social groupings, historical events, political practices, and expressions of consciousness. The fact that there exists no one definition of Diaspora attests to its usefulness as an analytical category through which to explore issues pertaining to identity politics, racial formation, and communalization to name a few.

The concept of African Diaspora, then, is most useful in exploring the unique experiences of Cape Verdean Americans as a racial/ethnic minority group whose life experiences have been similar to that of the larger African American community. By interpreting Cape Verdean American identity formation within an African Diasporic context, one can see the similarities of experience of racial discrimination and oppression that structure Black subjectivity as subordinate in the U.S. and worldwide. In short, situating Cape Verdean Americans within the African Diaspora of the U.S. can illustrate the historical, social, political, and economic experiences lived by Cape Verdean Americans as Blacks in the United States.

In this historical moment of expanding globalization, the concept of transnationalism has resurfaced, becoming increasingly important to theoretical discussions of Diaspora. ${ }^{18}$ Linda Basch, Nina Glick Schiller, and Cristina Szanton-Blanc define transnationalism as "the processes by which immigrants forge and sustain multi-stranded social relations that link together their societies of origin and settlement" (1994:7). This definition emphasizes the ways in which "transmigrants" maintain relationships that span across "geographic, cultural and political borders" (Basch, Glick Schiller, and Szanton-Blanc 1994:7). Although this definition of transnationalism places the experience of immigrants at its center, it can also be used to describe the experiences of later generations who maintain ties (actual and symbolic) with "the Old Country."

To consider Cape Verdean Americans a transnational community living in the United States is to acknowledge their unique lived experiences as an immigrant-descended group. Cape Verdean Americans are considered part of a transnational, "imagined" community not only because the constant flow of people, capital, technology and commodities between Diaspora and island-nation, but also because the government of Cape Verde recognizes the Diaspora as such (Pires-Hester 1994). ${ }^{19}$ Theories of transnationalism are useful in determining the impact of migration history and contemporary immigration on Cape Verdean American identity negotiation. For the purposes of my research, I employ the concepts of transnationalism and African Diaspora in combination as tools through which to interrogate the politics of racial and ethnic self-identification by Cape Verdean Americans as a people "dwelling-in-displacement" in the United States.

\section{RACE MATTERS}

When considering African Diaspora identity formation, the material consequences rendered by an adherence to "race" and/or "Blackness" as socially-constituted categories cannot be denied as a nexus of communalization. This is not to say that "Blackness" should be understood as a totalizing, one-dimensional 
concept. On the contrary, when implied within a Diasporic context, "Blackness" encompasses a multiplicity of experiences and identities. This is perhaps the most useful aspect of Diaspora. It suggests how race as a salient social construct is one of many modes of subjectivity responsible for the foundation of social organization and identity formation (see Gilroy 1993, Winant 1994). According to Omi and Winant 1986, racial meanings pervade racialized societies to such an extent that they subsequently impact the social relations of a given society on both the individual and collective levels. ${ }^{20}$ In other words, racial meanings have the potential to shape individual racial identities as well as collective political action (Omi \& Winant 1986:66). It is at this juncture that the Cape Verdean American "Black" experience is particularly illustrative.

During the initial wave of mass immigration, the majority of Cape Verdeans came from Brava and were light in complexion. Toward the turn of the nineteenth century, however, Cape Verdeans from Fogo and Santiago, who were generally darker in complexion, entered in greater numbers (Halter 1993:120). Yet, regardless of island of origin or phenotypic variety, the majority of Cape Verdeans entering into the United States acquired the status of "Black" by the dominant society, based on socially-constructed visual and "biological" (i.e., "African blood/ancestry") criteria. As Belmira Nunes recalls, "in the U.S., there was no middle ground. If you were dark, you were Black, and if you were anything different from White, you were Black unless you belonged possibly to the Yellow race" (1982:79). This type of racial ascription occurred especially when Cape Verdean Americans ventured outside of their immediate residential enclaves. As one Cape Verdean woman notes, "My children never knew they were Black until they went outside the neighborhood. The way I was brought up, you'd never say you were Black. You were Portuguese, you didn't hand around with Negroes. Now, we're taught to have pride [as Blacks]" (Sawyer 1980:Al).

Cape Verdean immigrants were not totally oblivious to racial doctrines that privileged light over dark. As suggested above, life in the islands under Portuguese colonial rule produced a racial hierarchy that promoted attitudes of superiority in those who closely approximated the European in phenotype. According to Goncalves, Cape Verdeans, the majority of whom were Mulattos, tended to distinguish themselves from those of pure ("unmixed") African descent (1983:114).

The intragroup prejudice facilitated by this system of social stratification has persisted, as is evidenced by the way Santiago natives are derogatorily referred to as Badius (Nunes 1982:5). Badius are actually the descendants of Maroon societies that live in the interior mountain areas of some of the islands. The term Badiu has since been generalized to describe all dark-skinned Cape Verdeans. As a child, I heard accounts related to how some Cape Verdeans "made fun of" Santiago natives. However, this was made most apparent to me recently prior to the 1995 Festival of American Folklife (FAF), when the planners of the Cape Verdean Connection program received complaints by some members of the Cape Verdean American community who were upset at the idea of being represented by Badius on the cover of the program's brochure.

Since the majority of Cape Verdeans living in the islands were Mestiço or Mulatto, "the vast majority viewed their society as basically homogeneous" (Rogers 1980:198). For this reason, most immigrants initially saw no need to claim a definitive "racial" identity (Goncalves 1983:113). Meintel Machado explains that, "In the rural areas, whence most of the immigrants originate, the question of identity remained implicit rather than a felt concern of everyday life. In this country [the United States], it became one of immediate importance" (1981:240). Once confronted by the racial hierarchy in place in the United States, Cape Verdean migrants became conscious of the fact that their skin tone and other phenotypic features proved disadvantageous in a society that categorizes individuals as either White or non-White, regardless of their particular cultural experience (Goncalves 1983:113). In other words, Cape Verdeans discovered quickly that "the American color spectrum had a very narrow White and a very broad Black band, but no center band corresponding to their reality [as "racially" mixed people]." Unlike their Portuguese immigrant counterparts, whose adoption of English, Anglicanizing of their surnames (Rogers 1980:199) ${ }^{21}$ and white skin helped facilitate their assimilation into mainstream society (Goncalves 1983:114), colorism dictated the status of Cape Verdeans as representative of a "minority among minorities" (Halter 1993:94).

Observing the racial discrimination experienced by African Americans, as well as the stigma attached to "Blackness," Cape Verdeans, during the early twentieth century, distanced themselves from a people that were similar to them in skin tone and 
phenotype. This was achieved by settling into ethnic enclaves and emphasizing their cultural distinctiveness (for example, language, religion [Catholicism], culinary traditions, etc.) (Halter 1993:147). Most importantly, Cape Verdeans during this time began to self-identify as either "Cape Verdean" or "Portuguese."

Cape Verdeans, in adopting a Portuguese identity, "spoke Portuguese rather than Crioulo in public situations, recognized the Portuguese flag and national anthem, and tried to join and participate in Azorean, Madeiran, and Continental Portuguese clubs" (Greenfield 1976:18). Moreover, as Meintel Machado contends,

Pursuit of a non-Black identity has usually involved denial or reinterpretation of certain Cape Verdean cultural items and historical experience. Crioulo was passed off as Portuguese, African-inspired musical forms largely forgotten, [and] the experience of slavery denied (1981:251).

For many, to identify with African Americans in a racist society would have hindered their chances for upward social and economic mobility. This is also the attitude held by some recent immigrants of African descent (e.g., Jamaicans, Haitians). ${ }^{22}$ These practices of limiting social interaction and exhibiting status-differentiating behaviors produced "bad blood" between the Cape Verdean American and African American communities, the latter referring to the former as traitors to their African heritage who wanted to be White. This was certainly my experience growing up in a small town in Massachusetts, where Cape Verdeans outnumbered the African American population. Despite my efforts at asserting my "Cape Verdeanness" and "Blackness," I was chastised by some African Americans for not "acting Black enough."

Thus, to call oneself "Cape Verdean" has been interpreted as a denial of one's African heritage. This misconception of Cape Verdean American self-identification still exists today. A similar experience was related to me by a participant of the FAF. Lara Barboza ${ }^{23}$ told me of her experiences as a Cape Verdean American student vis-à-vis her African American classmates in Boston, Massachusetts: "When I explain to them that I am Cape Verdean and explain Cape Verde, then they say 'oh, well then you're saying you're not Black.' Now, if I' $m$ saying I' $m$ from an African country, what am I denying?" For Lara, Cape Verdeanness and Blackness are intertwined into her existence by virtue of her imagination of the
African homeland of her relatives.

For Portuguese immigrants, Cape Verdeans defining themselves as Portuguese served as a hindrance for those wanting to assimilate into mainstream society. Pap explains that,

there can be no question but that in the U.S., the issue of skin color became considerably sharpened for immigrants from the Cape Verde Islands.... And since Cape Verdeans in the U.S. tended to categorize themselves to outsiders as Portuguese... this issue of skin color also acquired a very personal significance for the non-Cape Verdean Portuguese immigrants who wanted to avoid being considered non-White (1981:160).

Having experience with their own colonial color line established in Portugal, which distinguished the more swarthy southerner from the "White" northerner, the Portuguese were "quick to recognize the stigma of being labeled non-White in the United States and feared that in a system with such a rigid color line, they would also be classified as Black by virtue of association with the Cape Verdean settlers" (Halter 1993:148). As a result, Portuguese Americans began in the late nineteenth century to distinguish themselves as a raca portuguesa or "the Portuguese race" to emphasize their unique social, linguocultural, and political distance from others, especially from Cape Verdean Americans (Pap 1981:112). Portuguese American responses to Cape Verdean self-identification as Portuguese significantly ostracized Cape Verdeans from the Portuguese community and created a long-lasting social rift between the two groups of Portuguese ancestry (Goncalves 1983:115). Animosity still exists between Portuguese-Americans and Cape Verdean Americans, the latter referring to the former derogatorily as nhambobs (literally, "yam pickers/growers"). Within my hometown, this term is still invoked by Cape Verdeans referring to those "White" Portuguese who exhibit what they consider to be attitudes of superiority.

\section{BECOMING BLACK}

Despite their efforts of self-identification as either "Cape Verdean" or "Portuguese," Cape Verdean Americans experienced the reality of Jim Crow segregation as well as the empowerment of the Civil Rights and Black Power movements, which had an enormous impact on their collective identity formation. Other Black immigrant populations have been impacted in similar ways. With respect to the experience of 
non-English speaking immigrants of African descent, inclusive of Cape Verdeans, Ira De. A. Reid notes:

In the United States, individual members of this group - French, Spanish, or Portuguese-speaking though they may be, and though lacking any intra-group evaluation of race or color - become 'Colored,' 'Negro,' or 'African Black' as they encounter new standards, for races (1939:94).

Racial segregation and discrimination proved the most salient forces structuring Cape Verdean American "double consciousness"; that is, their dual sense of peoplehood, as Cape Verdean and Black. Concerning the social adjustment endured by Cape Verdeans as a result, Frances Ward notes that "Cape Verdeans, who had never considered themselves Blacks, suddenly found they were objects of harsh racial discrimination when they attempted to get certain jobs, live in certain neighborhoods or attend certain schools" (1975:A1, Col.1). Many Cape Verdeans first encountered Jim Crow segregation upon enlistment in the armed forces during World War II. Again, on the basis of skin color, Cape Verdeans were assigned to either Black or White units. However, according to Marilyn Halter, "Most were sent to Black regiments where they were forced to deal directly with the issue of race, both in terms of the racist treatment they received in the military and in having to confront the question of their own racial identification" (1993:163). Greenfield adds that,

To their shock and dismay, in contrast with their views of themselves as Cape Verdeans, Bravas, or at worst "Black Portuguese," to American society, at least as represented by its military, they were niggers, coloreds not to be differentiated in treatment from others of African descent. Hence, Cape Verdeans served in segregated units, learning first hand and emphatically what it was like to be a Black man in a White man's world (1976:8).

The sixties had a tremendous impact on Cape Verdean identity construction. It was during this time that Blackness and African heritage in particular were de-stigmatized for most Americans of African descent; and especially for second and third generation Cape Verdean Americans who, under the influence of the Civil Rights, Black Power, and African liberation movements, began to align themselves politically and culturally with African Americans. This was true of my aunt and uncle who, as college students, began wearing Afro hairstyles and tried to convince my grandmother and other older Cape Verdeans in the neighborhood, that Cape Verdeans and African Americans were "Black" and not "Colored."

The creation of a politicized "Black/Cape Verdean" identity has had significant repercussions that are evident in the contemporary Cape Verdean American community. As Lucy Ramos states, "I think that our children are now beginning to realize also that they can identify as Black and still retain their Cape Verdean heritage" (Reardon 1982:35). Many of the younger Cape Verdean Americans, unlike their elders, now emphasize their African ancestry and view Cape Verde as part or a republic of Africa, as the case of Lara Barboza illustrates.

Unlike previous generations who self-identified as "Cape Verdean" as a means of distancing themselves from the stigma attached to being Black in the United States, the young Cape Verdean Americans students I had the opportunity to speak with during the FAF insisted that their identification as Cape Verdeans is not a denial but an affirmation of their African ancestry. More and more Cape Verdean Americans are asserting a discourse of "Blackness" that situates their racial, political, and socioeconomic status and that of African Americans on an equal footing, that is, in the context of both Cape Verdeans and African Americans belonging to the African Diaspora living in the United States.

\section{A 'BLACK ATLAN'TIC' PEOPLE}

Cape Verdean Americans, given their social history as "Black immigrants" in the United States, can be considered members of the African Diaspora living in this country. Gilroy's concept of the Black Atlantic highlights the linkages among Black cultures worldwide, as solidified by shared historical and ongoing transnational interactions. Unlike Gilroy, who identifies the Middle Passage as the common historical moment of conjuncture for the Black Atlantic, I suggest an idea of African Diasporic identity formation that considers a common experience of "racial" oppression of those who are ascribed a racialized status as Black. In this sense, the Cape Verdean "Black" experience is shared not only by African Americans but also by other immigrants of African descent now residing in the United States.

With respect to ascription and self-identification, as dual mechanisms of identity formation along the lines of a socially-constituted, "racial" appearance, David Lopez' (1990) concept of panethnicity is also useful in delineating Cape Verdean 
American Diasporic identity. Lopez contends that in general, "when subgroups 'look alike' from the perspective of the outsider, they experience a powerful force for panethnic solidarity" (1990:203). Lopez' conceptualization of panethnic solidarity may explain why some Cape Verdean Americans make the political choice to define themselves as Black or members of the African Diaspora, while others choose to downplay their Cape Verdean cultural heritage all together. Another example is if a Cape Verdean American who is a member of a Cape Verdean and an African American organization chooses to emphasize their cultural or racial identities given the specific sociocultural context of the organization's activities (e.g., Kwanzaa versus San Jon celebrations). Again, outside of physical appearance, solidarity between Cape Verdeans and African Americans has also been fostered by their mutual experience of racial discrimination endured as Black people in the U.S.

Self-identification is characterized by a group's capacity to self-organize and internally define their sense of identity (Adams n.d.:4). Cape Verdean American self-identification has become an increasingly political exercise. The process of constructing one's identity in the face of a somewhat static classification system does not occur in a vacuum, however. An important aspect of the process of collective group identity formation involves the social interaction that occurs between groups. Through such interactions, racial and ethnic groups in particular are prompted to fortify and protect criteria or boundaries that aid in defining the collective identity of its members and thus marking the group as culturally distinct (Barth 1969). Greenfield notes that,

The numerous interactions between the members of self-perceived groups and others result in the acceptance and recognition, or rejection of an identity for the group members. The process is a continuing one that is subject to constant redefinition and change (1976:5).

Like other immigrant groups of African descent, Cape Verdeans have traditionally settled near or within areas heavily populated by African Americans and other racial/ethnic minority groups, especially within large urban locales like Boston or New York. In light of this fact, the ways in which Cape Verdean Americans negotiate their "Blackness" has much to do with their close associations with African Americans in educational, occupational, and residential environments. This, of course, is by no means a new phenomenon. Cape Verdeans' historical involvement in traditional African American volunteer associations (e.g., NAACP, longshoremen associations, Black fraternities and sororities) attests to this fact.

Likewise, Karen Blu comments on the aspect of ethnicity relevant to Cape Verdean social relations when she argues that:

Some people choose to minimize their ethnicity, rarely interacting with others of similar ethnic identity and ignoring whatever traditional aspects that might be associated with such an identity. Others choose to live within a community that strongly emphasizes its ethnicity, proudly and explicitly carrying on traditions associated with it (1980:210).

Again, some Cape Verdean Americans may choose to participate only in Cape Verdean cultural events, whereas others may have thoroughly assimilated into the larger African American community. Thus, Cape Verdean American self-identification entails some degree of flexibility. At the same time, it is both a group and an individual activity, contingent upon both shared cultural values and political agendas.

Cape Verdean American attempts at self-identification have been described as one of being "unseen," in that their own self-representations did not match the "assigned" socially-designated ones, the latter often proving more salient (Halter 1993:10). When given the option to self-identify, persons of Cape Verdean descent have done so in a multiplicity of ways over the years: as Portuguese, Cape Verdean, African, Black, "Afro-American," or Cape Verdean-American. Contemporary instances of Cape Verdean self-identification indicate the same degree of flexibility. Greenfield identifies four "strategies" that Cape Verdeans have utilized since the post-World War II era: Cape Verdean-Portuguese; Cape Verdean-Black; Cape Verdean-African; and Cape Verdean-American (1976:10). He qualifies his historical contextualization by stating that "the strategies are fluid, and their utility and possible advantage relates perhaps more to the trends in the larger society than to the wishes of the Cape Verdean themselves" (1976:15). Likewise, Goncalves identifies five "options" used by Cape Verdeans, each indicative of a political stance: Cape Verdean; Portuguese; Cape Verdean-American; African-American; and American (1983:116).

It is important to remember that each of the above identity constructs are indicative of individual and/or collective lived experience that involves a 
negotiation between racial ascription and self-identification. As for myself, my experiences have shaped my politicized identity as African American, Cape Verdean and Puerto Rican. In short, when considering contemporary Cape Verdean American self-identification as constructed in the United States, one must keep in mind the politics involved. Implied is the phenomenon of transforming bureaucratic labels into politically significant ones which, in turn, impact personal identities. In addition, identity is constructed and negotiated in relation to other groups and is contingent upon collective self-conception as well as outside perception. However, the social constraints under which these identities are constructed must also be critically assessed; when confronted with a system of racial dichotomy, Cape Verdean Americans tend to designate themselves as "Black" or people of color more often than as White (Halter 1993:173).

\section{CONCLUSION}

The United States houses a society motivated by political and economic factors to classify its citizens according to race and ethnicity. Because this racialized society does not adequately account for groups of ambiguous (i.e., mixed) "race" and ethnicity, Cape Verdean Americans may always be recognized as people of color or non-White, despite their efforts at self-representation.

Cape Verdean emigration from the islands, forced or voluntary, constitutes a transnational movement warranting sociocultural adjustment upon settlement into a new locale. Since some Cape Verdeans today still refer to themselves as Portuguese, practice Catholism as do Portuguese Americans, speak Portuguese in formal settings, and have similar cultural traditions as Portuguese Americans, they are often defined as more culturally congruent with the Portuguese. Yet, the experiences of Cape Verdean Americans living in the U.S. reveal that their identities are often articulated as a composite of racial and ethnic categories. Their experiences with racial ascription in particular have prompted the construction of a social, "Black" identity.

It is for this reason that they can be considered members of the African Diaspora residing in the United States. Situating Cape Verdean Americans within an African Diasporic context serves two purposes: to illustrate the multifaceted nature of the African Diaspora; and to dispel misrepresentations of the African-descended community of the United States as a monolithic group. For those Cape Verdean
Americans who have lived a "Black" experience as a result of this country's system of racial classification, practice of racial discrimination and promotion of cultural intolerance, the concept of the African Diaspora illuminates the processes through which Cape Verdean-descended people negotiate their identity as multiple and transgressive. In other words, it has the potential to highlight the ways in which Cape Verdean Americans imagine themselves as members of both the Cape Verdean and Black (African American) communities of the United States.

\section{Notes}

I would like to thank Edmund T. Gordon, Pauline Turner Strong and Kia C. Lilly for their critical readings of early versions of this paper. A portion of the research for this paper was conducted during the summer of 1995, when I was a Graduate Fellow at the Smithsonian Institution's Center for Folklife Programs and Cultural Studies. I extend my appreciation to John W. Franklin, program co-curator, and Raymond Almeida, senior program advisor/fundraising coordinator, for their guidance during my brief residence, and for their ongoing support of my research. An oral version of this paper was presented to the Department of Anthropology, at the University of Texas, Austin, and during the American Ethnological Society's annual meeting, April, 1996, on a panel entitled Culture, Politics and Historical Memory in the African Diaspora, which I and Kia C. Lilly co-organized. I thank Kamala Visweswaran for her helpful comments during both presentations.

1. The term "Cape Verdean Americans," employed throughout, is a general descriptor of a population whose members identify themselves or are identified by others as such. They are also a group that traces its ancestry and/or that of their relatives to the Cape Verde Islands. The "American" aspect of this descriptor distinguishes second and later generations from first generation migrants, specifically indicating persons of Cape Verdean ancestry who were born in the United States. The term is also used to describe a racial/ethnic community comprised of both citizens (native and naturalized) and residents (legal and illegal) currently living (temporarily and permanently) in the United States.

2. The discourse on ethnic choice has centered around the ability of Americans of European descent (primarily), especially those of multiethnic 
ancestries, to either choose which ethnicity they wish to identify with most (e.g., Italian over Irish), or to ignore ethnicity altogether by identifying themselves as "White" or "American." For Americans of African descent, however, because of the prevalence of racial categorization in our society, "Black" and more recently "African American" have been the only ethnic options. For a more detailed discussion on the construction of ethnic identity as it pertains to European and African Americans, see Lieberson (1985), Nagel (1994), Roosens (1989), and Waters (1990).

3. The terms race and ethnicity, employed throughout without quotations, are defined here as socially constructed concepts that nevertheless have real material effects on those whose everyday lives are shaped by these discursive categories. For the purpose of this paper, race is defined as a category used to distinguish persons according to perceived physical difference; whereas ethnicity is understood as a category used to distinguish persons according to cultural practice. The author acknowledges the conceptual overlap of these terms as well as the social constructedness of the criteria used to define them.

4. The Sotavento (Windward) islands include: Brava, Fogo, Santiago (Sao Tiago), and Maio. The Barlavento (Leeward) islands consist of: Boa Vista, Sal, Santa Luzia, Sao Nicolau, Sao Vicente, and Santa Antao.

5. This term was invoked by Cape Verdean community scholars, such as Raymond Almeida, at various times during the Smithsonian's 1995 Festival of American Folklife (FAF), at which time the researcher was a Graduate Fellow of the Center of Folklife Programs and Cultural Studies (CFPCS), Smithsonian Institution. During this time, the CFPCS co-sponsored its annual Festival of American Folklife during which Cape Verdean and Cape Verdean American cultures were featured.

6. For a discussion of this theory and the history of slavery in Cape Verde, see Antonio Carreira, Cabo Verde: formacao de uma sociedade escravocrata, 1460-1878, (Porto: Impresa Portuguesa, 1972), pp. 294-95 (cited in Halter 1993:2).

7. Similar to Brazil, colonial Cape Verde utilized the term "preto" instead of "negro" to categorize persons of "apparent African cultural or racial origin" (Lobban, 1995:54). "Negro" or "blak" (in Kriolu) was considered a pejorative connotation, similar to the racial slur "nigger" used in the United States (Halter 1993:151).
8. The national (i.e., unofficial) language of Cape Verde is Kriolu, a language derived from Portuguese and various West African languages. Kriolu is a distinct, pidginized language that is often mistaken for a dialect of Portuguese. A clear distinction can be made between the Kriolu spoken in the Sotavento islands and that which is spoken by the Barlavento group, which I witnessed first-hand at the FAF. Efforts have been made in the last two decades in both the islands and in the U.S. to standardize the orthography of this traditionally oral language.

9. In addition to those entering the U.S., some Cape Verdeans chose to settle in Portugal, Senegal, Holland, Great Britain, and France. Others entered involuntarily into Sao Tome and Principe, Angola, and Guinea-Bissau as forced laborers for plantation work. The latter individuals were either kidnapped or tricked into what they thought was a contractual labor negotiation; most left the islands, never to see their families again (See Foy 1988:15).

10. Cape Verdeans also immigrated to other parts of the United States, including Hawaii and California. Those entering into Hawaii did so as contract laborers for work on sugar plantations; whereas those who immigrated to California worked as farmers, dairy ranchers, gardeners, and railroad hands (see, Rogers 1980:198). Unlike the Cape Verdeans who went to Hawaii, who thoroughly merged through miscegenation into the general population, the California Cape Verdeans maintained their status as a distinct racial/ethnic enclave. There is a significant amount of Cape Verdeans presently living in the Sacramento, San Francisco and Los Angeles areas of California.

11. The packet trade is also referred to as the "Brava Packet Trade," because most of the maritime trade and early immigration occurred through the port of Furna on the island of Brava.

12. Cape Verdean immigrants and their descendents also worked as seasonal laborers for the strawberry and blueberry harvesting industries of New England.

13. The National Origin Quota Act or First National Origins Act of 1921 placed a cap on European immigration by limiting the annual number of visas from each country to $3 \%$ of the number of U.S. compatriots counted in the 1910 Census (see, Hull 1985:18). The Johnson-Reed Act of 1924, also referred to as the Second National Origins Act, was enacted from 1929 to 1965 . This act further limited the quota for Europeans, to a total of no more than 
150,000 in one year. As an amendment to the 1921 act, the act of 1924 limited the annual number of visas to $2 \%$ of the number of U.S. compatriots counted in the 1890 Census (see, Hull 1985:18). Farley \& Allen (1987) contend that the acts of 1921 and 1924 also sought to curtail Black immigration. During these years of immigrant restriction, Cape Verdeans immigrated to other countries, such as Portugal, France, Holland, Senegal, Argentina, and Brazil.

14. The McCarran-Walter Act of 1952, also known as the Immigration and Nationality Act, fixed the number of visas for different groups as follows: for Asians, 2,990; Africans, 1,400; and Europeans, 149,667 . Although this act is known for its apparent lifting of racial quotas, admittance was still based on the "relative desirability of different ethnic groups" (see, Hull 1985:21). The Immigration and Nationality Amendment of 1965, or the Hart-Celler Act increased the annual number of country visas to 20,000 per year starting in 1968, without exceeding a total limit of 170,000 in one year. The quota for the Western hemisphere, however, which included Mexico and the West Indies, was set at 120,000 visas per year (see, Hull 1985:22). This act negatively affected Cape Verde and Portugal; according to this act, the visa quota for colonies and dependencies was set at 200 per year, which counted against the quotas set for the colonial empire and hemispheric quotas (Hull 1985:23). A 1976 amendment raised this quota to 600 and in 1978, an amendment placed a worldwide ceiling on immigration, 290,000 per year (Hull 1985:25). Although the legislation of 1978 liberalized immigration, admission was still determined on a country by country basis, which, again, facilitated discriminatory ratios based on the most "desirable" (e.g., ethnicity, skills) immigrants (Hull 1985:27).

15. These self-designations are questionable given the fact that the term "Brava" in particular originated as a term used by Yankee whalers when referring to their crewmembers (from Brava). Later, Anglo-Americans used the term to refer to all Cape Verdean immigrants, regardless of island of origin. Whether or not Cape Verdean Americans thereafter adopted the term as a means of self-classification remains open for debate.

16. In his discussion of development of nation-states, Benedict Anderson conceptualizes the "imagined community" as one whose members are bound to each other through the idea of themselves as constituting a collectivity which "may never know most of their fellow-members" (Anderson, 1991[1983]:6).
To call the island of Brava, for example, an imagined community is a means of illustrating the sense of connectedness often felt between Cape Verdean Americans whose relatives come from that particular island.

17. From its onset in 1790 until 1970, the Census enabled the documentation of first and second generation immigrants through the question of birthplace (of individual and parents). After 1970, however, this question was no longer available. In 1980 and 1990, the Census added the question of ethnic ancestry that was to be asked of all persons within the household. This question was included on the long form which was distributed to one out of every five households in the country. The question allowed the individual to provide up to three responses. Its instructions referred specifically to Cape Verdean Americans with the statement, " Be specific: Distinguish Cape Verdean from Portuguese." Although the deletion of the birthplace question obscures data on geographic and cultural origins, the question of ethnic ancestry provides data on later generations of immigrant families that were previously unattainable (see, Waters 1990).

18. Immigration to the U.S., as historically rooted in the processes of colonization, enslavement, and contractual labor arrangments, renders discussions of transnationalism dated, despite its recent elevation in academic currency.

19. This is similar to the example of the Haitian Diaspora in the U.S. and their formal recognition by President Aristide as the "Tenth Department" of Haiti.

20. For a detailed discussion of racial formation theory, see, M. Omi and H. Winant, Racial Formation in the United States: 1960s to the 1980s (New York: Routledge, 1986). In addition, for a critical reading of Omi \& Winant, see, E. San Juan, Jr., Racial Formations/Critical Transformations: Articulations Of Power In Ethnic And Racial Studies In The U.S. (New Jersey: Humanities Press, 1992).

21. This practice was common among many ethnic groups immigrating to this country, including Cape Verdeans. However, those Cape Verdeans who did change their names did so as a means of assimilating into the African American community (e.g., Barros - Barrows).

22. I found the following texts the most useful in the study of the "Black immigrants": Kristen F. Butcher, "Black Immigrants In The United States: A Comparison With Native Blacks And Other 
Immigrants." Industrial And Labor Relations Review 47(2) (1994):265-284; Christine G.T. Ho, "The Internationalization Of Kinship And The Feminization Of Caribbean Migration: The Case Of Afro-Trinidadian Immigrants In Los Angeles." Human Organization 52(1) (1993):32-41; Phillip Kasinitz, Caribbean New York: Black Immigrants And The Politics Of Race (Ithaca, NY: Cornell University Press, 1992); Maxine L. Margolis, Little Brazil: An Ethnography Of Brazilian Immigrants In New York City (Princeton: Princeton University Press, 1994); David Mittelberg, and Mary C. Waters, "The Process Of Ethnogenesis Among Haitian And Israeli Immigrants In The United States." Ethnic And Racial Studies 15 (1992):412-435; John Ogbu, "Immigrant And Minorities In Comparative Perspective." In Minority Status and Schooling: A Comparative Study Of Immigrant and Involuntary Minorities. M. Gibson \& J. Ogbu, eds. (New York: Garland, 1991); and Mary C. Waters, "Ethnic And Racial Identities Of Second-Generation Black Immigrants In New York City." International Migration Review 28(4) (1994):795-821.

23. Pseudonym.

\section{References Cited}

Abu-Lughod, Lila

1986 Writing Against Culture. In Recapturing Anthropology: Working in the Present. Richard G. Fox, ed. Pp. 137-162. Santa Fe, NM: School of American Research Press.

Adams, Richard N.

n.d. Internal and External Ethnicities: With Special Reference to Central Americans. Texas Papers on Latin America. Working Paper \#89-03. Austin: Institute of Latin American Studies, University of Texas.

Almeida, Raymond A.

1978 Cape Verdeans in America: Our Story. Boston: TCHUBA American Committee for Cape Verde.

Anderson, Benedict

1991[1983] Imagined Communities: Reflections on the Origin and Spread of Nationalism. 2nd ed. New York: Verso Press.

Appiah, Kwame Anthony

1992 In My Father's House. Oxford: Oxford University Press.
Barrows, Paul

1990 The Historical Roots of Cape Verdean Dependency, 1460-1990. Ph.D. Diss., University of Minnesota.

Barth, Fredik

1969 Introduction. In Ethnic Groups and Boundaries: The Social Organization of Cultural Difference. Pp. 9-53. Boston: Little Brown.

Basch, Linda, Nina Glick Schiller and Cristina Szanton Blanc

1994 Nations Unbound: Transnational Projects, Postcolonial Predicaments, and De-territorialized Nation-states. Amsterdam: Gordon and Breach Publishers.

Blu, Karen

1980 The Lumbee Problem. New York: Cambridge University Press.

Boyarin, Daniel and Jonathan Boyarin

1993 Diaspora: Generation and the Ground of Jewish Identity. Critical Inquiry 19:693-725.

Brown, Don

1987 Black Whalers: They Were Great While It Lasted. American Visions [October]:26-30.

Bryce-Laporte, Roy Simon

1972 Black Immigrants: The Experience of Invisibility and Inequality. Journal of Black Studies 1:29-56.

Butcher, Kristin F.

1994 Black Immigrants in the United States: A Comparison with Native Blacks and Other Immigrants. Industrial and Labor Relations Review 47(2):265-284.

Campisi, Jack

1991 The Mashpee Indians: Tribe on Trial. New York: Syracuse University Press.

Clifford, James

1994 Diasporas. Cultural Anthropology

Cubie, Bob 9(3):302-338.

1994 Series on Cape Verdeans in Brockton: Cape Verdeans Prospered on Land and on Sea. The Enterprise 10 May 1994, A1+pl.6.

D'Alessandro, Joe

1983 Sacramento's Portuguese Heritage, 1849-1983: A Pioneer Community. In Portugueses na America do Norte. Eduardo Mayone Dias, ed. P.73. Lisbon: Peregrinacao. 
D'Eca, Raul

1980[1939] The Portuguese in the United States. In Portuguese Americans and Spanish Americans. Carlos E. Cortez, ed. P. 367. New York: Arno Press.

Davidson, Basil

1989 The Fortunate Isles: A Study in African Transformation. Trenton, NJ: African World Press, Inc.

Drake, St. Clair

1982 Diaspora Studies and Pan-Africanism. In Global Dimensions of the African Diaspora Joseph E. Harris., ed. Washington, D.C.: Howard University Press.

Farley, Reynolds, and Walter R. Allen

1987 The Color Line and the Quality of Life in America. New York: Russell Sage Foundation.

Foner, Nancy

1987 Introduction: New Immigrants and Changing Patterns in New York City. In New Immigrants in New York. Nancy Foner, ed. Pp. 1-33. New York: Columbia University Press.

Foy, Colm

1988 Cape Verde: Politics, Economics, and Society. London: Pinter Publishers, Ltd.

Gilroy, Paul

1987 There Ain't No Black in the Union Jack. London: Hutchinson.

1993 The Black Atlantic: Modernity and Double Consciousness. Cambridge, MA: Harvard University Press.

Goncalves, Jose da Silva

1983 A Comunidade Cabo-Verdiana Nos Estados Unidos: Um Caso de Ambiguidade Cultural. In Portugueses na America do Norte. Eduardo Mayone Dias, ed. Lisbon: Peregrinacao.

Greenfield, Sidney M.

1976 In Search of Social Identity: Strategies of Ethnic Identity Management Amongst Capeverdeans in Southeastern Massachusetts. Luso-Brazilian Review 13(1):3-17.

Halter, Marilyn

1993 Between Race and Ethnicity: Cape Verdean American Immigrants, 1860-1965. Urbana: University of Illinois Press.
Helmreich, Stefan

1992 Kinship, Nation, and Paul Gilroy's Concept of Diaspora. Diaspora 2(2):243-249.

Hull, Elizabeth

1985 Without Justice For All: The Constitutional Rights of Aliens. Westport, CT: Greenwood Press.

Lavie, Smadar and Ted Swedenburg

1996 Introduction. In Displacement, Diaspora and Geographies of Identity. Smadar Lavie and Ted Swedenburg, eds. Pp. 1-25. Durham: Duke University Press.

Lieberson, Stanley

1980 A Piece Of The Pie: Blacks And White Immigrants Since 1880. Berkeley: University Of California Press.

Lobban, Richard

1995 Cape Verde: Crioulo Colony to Independent Nation. Boulder: Westview Press.

Lobban, Richard, Waltraud Berger Coli and R. Tidwell

1985 Patterns of Cape Verdean Migration and Social Association: History through Obituary Analysis. New England Journal of Black Studies 5:31-45.

Lopez, David

1990 Panethnicity in the United States. Ethnic and Racial Studies 13:198-224.

Meintel, Deirdre

1984 Race, Culture, and Portuguese Colonialism in Cabo Verde. New York: Syracuse University, Maxwell School of Citizenship and Public Affairs.

Meintel Machado, Deirdre

1981 Cape Verdean Americans. In Hidden Minorities: The Persistence of Ethnicity in American Life. Joan H. Rollins, ed. Pp. 233-256. Washington, D.C.: University Press of America.

Mercer, Kobena

1994 Introduction: Black Britain and the Cultural Politics of Diaspora. In Welcome to the Nagel, Joane Jungle. New York: Routledge.

1994 Constructing Ethnicity: Creating and Recreating Ethnic Identity and Culture. Social Problems 41(1):152-172. 
Nunes, Maria Luisa

1982 A Portuguese Colonial in America: Belmira Nunes Lopes, The Autobiography of a Cape Verdean-American. Pittsburg, PA: Latin American Literary Review Press.

Omi, Michael and Howard Winant

1986 Racial Formation in the United States: From the 1960s to the1980s. New York: Routledge Press

Padmore, George

1956 Pan-Africanism or Communism? London: Dennis Dobson.

Pap, Leo

1981 The Portuguese-Americans. Boston: G.K. Hall and Co.

Pires-Hester, Laura J.

1994 A Study of Cape Verdean-American Ethnic Development: The Emergence of Bilateral Diaspora Ethnicity and its Impact in a Southeastern New England Locality. Ph. D. Diss., Columbia University.

Reardon, John C.

1982 Black, White or Portuguese? A Cape Verdean Dilemma. In Spinner: People and Culture of Southeastern Massaachusetts. Pp. 34-37. New Bedford, MA: Spinner Publications.

Reid, Ira De. A.

1939 The Negro Immigrant: His Background, Characteristics and Social Adjustment, 1899-1937. New York: Columbia University Press.

Rogers, Francis M.

1980 Cape Verdeans. In Harvard Encyclopedia of American Ethnic Groups. Stephan Thernstrom, ed. Pp. 197-200. Cambridge: The Belknap Press of Harvard University Press.

Roosens, Eugeen E.

1989 Creating Ethnicity: The Process of Ethnogenesis. Newberry Park: Sage Publications.

Sánchez, George J.

1993 Becoming Mexican American: Ethnicity, Culture and Identity in Chicano Los Angeles, 1900-1945. New York: Oxford University Press.

Sawyer, Kathy

1980 Cape Verdeans Face Identity Problem in United States. Washington Post, 6 July 1980, Al+pl.6.
Walters, Ronald W.

1993 Postscript: Culture and Politics in the African Diaspora. In Pan Africanism in the African Diaspora. Detroit: Wayne State University Press.

Ward, Francis

1975 Cape Verdean - Mixed Race Seeks Identity. Los Angeles Times, 23 June 1975, Al, Col.1+A10, Col.1.

Waters, Mary C.

1990 Ethnic Options: Choosing Identity in America. Berkeley: University Of California Press.

1994 Ethnic and Racial Identities of Second-Generation Black Immigrants in New York City. International Migration Review 28(4):795-821.

Williams, Jerry

1983 Where are They Now? Locational Characteristics of Portuguese-Americans. In Portugueses na America do Norte. Eduardo Mayone Dias, ed. P. 27. Lisbon: Peregrinacao.

Winant, Howard

1994 Racial Conditions. Minneapolis: University of Minneapolis Press.

Woldemikael, Tekle Mariam

1989a A Case Study of Race Consciousness Among Haitian Immigrants. Journal of Black Studies 20(2):224-239.

1989b Becoming Black American: Haitians and American Institutions in Evanston, Illinois. New York: AMS Press, Inc.

Wolforth, Sandra

1978 The Portuguese in America. San Francisco: R. \& E. Research Associates, Inc. 